\title{
The Effects of Persistent Olfactory and Gustatory Dysfunctions on Quality of Life in Long-COVID-19 Patients
}

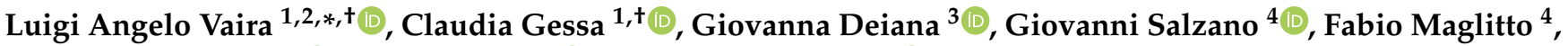 \\ Jerome R. Lechien $\left.{ }^{5,6}{ }^{(}\right)$, Sven Saussez ${ }^{5}$, Pasquale Piombino ${ }^{\circledR}$, Andrea Biglio ${ }^{1,7}$, Federico Biglioli ${ }^{7}$, \\ Paolo Boscolo-Rizzo ${ }^{8}$, Claire Hopkins ${ }^{9,10}$, Valentina Parma ${ }^{11,12, \ddagger}$ and Giacomo De Riu ${ }^{1,2, \ddagger}$
}

check for updates

Citation: Vaira, L.A.; Gessa, C.; Deiana, G.; Salzano, G.; Maglitto, F.; Lechien, J.R.; Saussez, S.; Piombino, P.; Biglio, A.; Biglioli, F.; et al. The Effects of Persistent Olfactory and Gustatory Dysfunctions on Quality of Life in Long-COVID-19 Patients. Life 2022, 12, 141. https://doi.org/ 10.3390/life12020141

Academic Editor: Giuseppe Ricci

Received: 19 December 2021

Accepted: 17 January 2022

Published: 19 January 2022

Publisher's Note: MDPI stays neutral with regard to jurisdictional claims in published maps and institutional affiliations.

Copyright: (C) 2022 by the authors. Licensee MDPI, Basel, Switzerland. This article is an open access article distributed under the terms and conditions of the Creative Commons Attribution (CC BY) license (https:// creativecommons.org/licenses/by/ $4.0 /)$.
1 Maxillofacial Surgery Operative Unit, Department of Medical, Surgical and Experimental Sciences, University of Sassari, 07100 Sassari, Italy; c.gessa@studenti.uniss.it (C.G.); andreabiglio@gmail.com (A.B.); gderiu@uniss.it (G.D.R.)

2 Biomedical Science Department, PhD School of Biomedical Science, University of Sassari, 07100 Sassari, Italy

3 Direction, Hygiene and Hospital Infection Control Operative Unit, Department of Medical, Surgical and Experimental Sciences, University of Sassari, 07100 Sassari, Italy; giovanna.deiana90@gmail.com

4 Maxillofacial Surgery Department, University Hospital of Naples "Federico II", 80131 Naples, Italy; giovannisalzanomd@gmail.com (G.S.); fmaglitto@gmail.com (F.M.); piombino@unina.it (P.P.)

5 Department of Human and Experimental Oncology, Faculty of Medicine UMONS Research Institute for Health Sciences and Technology, University of Mons (UMons), 7000 Mons, Belgium; jerome.lechien@umons.ac.be (J.R.L.); sven.saussez@umons.ac.be (S.S.)

6 Department of Otolaryngology-Head \& Neck Surgery, Foch Hospital, School of Medicine, UFR Simone Veil, Versailles Saint-Quentin-en-Yvelines University, Paris Saclay University, 91190 Paris, France

7 Maxillofacial Surgery Department, San Paolo Hospital, ASST Santi Paolo e Carlo, University of Milan, 20122 Milan, Italy; federico.biglioli@unimi.it

8 Department of Medicine, Surgery and Health Sciences, University of Trieste, 34149 Trieste, Italy; pboscolorizzo@yahoo.it

9 Guy's and St Thomas NHS Foundation Trust, London SE1 7EH, UK; clairehopkins@yahoo.com

10 British Rhinological Society (President), London WC2A 3PE, UK

11 Monell Chemical Senses Center, Philadelphia, PA 19104, USA; vparma@monell.org

12 Department of Psychology, Temple University, Philadelphia, PA 19122, USA

* Correspondence: lavaira@uniss.it; Tel.: +39-340-1846168

$+\quad$ These authors contributed equally to this work and should be regarded as joint first authors.

$\ddagger \quad$ These authors contributed equally to this work and should be regarded as joint senior authors.

Abstract: (1) Background: Persistent olfactory (POD) and gustatory (PGD) dysfunctions are one of the most frequent symptoms of long-Coronavirus Disease 2019 but their effect on the quality of life (QoL) of patients is still largely unexplored. (2) Methods: An online survey was administered to individuals who reported to have had SARS-CoV-2 infection at least 6 months prior with persisting COVID19 symptoms (using the COVID symptom index), including ratings of POD and PGD, and their physical (PCS) and mental (MCS) components of quality of life were assessed using the standardized short form 12 questionnaire (SF-12). (3) Results: Responses from 431 unique individuals were included in the analyses. The most frequent persistent symptoms were: fatigue (185 cases, $42.9 \%)$, olfactory dysfunction (127 cases, 29.5\%), gustatory dysfunction (96 cases, $22.3 \%$ ) and muscle pain (83 cases, 19.3\%). Respondents who reported persisting muscle pain, joint pain, fatigue, headache, gastrointestinal disturbances, and dyspnea had significantly worse PCS. Those experiencing persistent fatigue and dyspnea also showed significantly lower MCS. Respondents reporting POD or PGD showed significantly worse QoL, but only pertaining to the MCS. Multiple regressions predicted MCS based on olfactory and marginally on gustatory ratings, but not PCS. Age significantly affected the prediction of PCS but not MCS, and gender and temporal distance from the COVID-19 diagnosis had no effect. (4) Conclusions: POD and PGD are frequent symptoms of the long-COVID-19 syndrome and significantly reduce QoL, specifically in the mental health component. This evidence should stimulate the establishment of appropriate infrastructure to support individuals with persistent CD, while research on effective therapies scales up. 
Keywords: smell; taste; olfactory disorders; gustatory disorders; anosmia; ageusia; long-COVID-19; quality of life; SARS-CoV-2

\section{Introduction}

Persistent olfactory (POD) and gustatory (PGD) dysfunctions, together known as chemosensory dysfunction (CD), are among the most frequent symptoms of long-Coronavirus Disease 2019 (long-COVID-19) [1]. The first studies with follow-up at 6 [2-9] and 12 months [10-12] show high prevalence of persistent $\mathrm{CD}$ in up to $67 \%$ of participants who had a symptomatic infection with severe acute respiratory syndrome coronavirus 2 (SARS-CoV-2). Given the high prevalence of CD in individuals with first-time COVID-19, their high frequency in individuals experiencing reinfections $[13,14]$ and in those vaccinated against COVID19 [15], CD will represent a serious health problem in the near future. Unlike other sensory deficits, the impact of $\mathrm{CD}$ on the individual's well-being is often overlooked or minimized by those who do not routinely deal with these pathologies [16]. Nonetheless, the integrity of the olfactory and gustatory perception provides key support to well-being significantly impacting nutrition, social behavior and the ability to protect oneself from environmental dangers [17].

Despite the presence of $\mathrm{CD}$ having been deemed a favorable prognostic factor for the acute phase of COVID-19 [18-20], CD is associated with increased levels of anxiety and depression [21,22]. While there is sufficient evidence to indicate that $C D$ is associated with reduced quality of life (QoL) [23-25], on the other hand the effects of CD on the QoL of patients with long-COVID-19 remain significantly underexplored. Burges Watson et al. [26] conducted a text analysis of posts generated by 9000 users on a Facebook group that brought together individuals with COVID-19-related CD. Users with CD reported a broad spectrum of circumstances that reduced their wellbeing, such as work or study difficulties, impaired eating with loss of appetite and weight changes, social and interpersonal limitations. Additionally, Ohla and colleagues [27] in their pre-print suggest that POD in the acute phase of the disease is associated with more COVID-19 symptoms overall and may represent a key marker of long-COVID-19.

A recent review of the literature [28] looking for studies on the impact of $\mathrm{CD}$ on QoL in COVID-19 found only four studies published so far [29-32]. These studies share some limitations which call into question the robustness of the conclusions made. First, the use of validated QoL questionnaires is essential to obtain reliable data and provide meaningful comparisons with normative groups [33], but three out of those four studies based their conclusions only on self-reported QoL [29-31]. Second, all studies investigate QoL at less than 3 months from COVID-19 diagnosis, a time period in which there are high rates of spontaneous recovery and the full impact of $C D$ on well-being may not be apparent. More appropriate follow-up time points are a minimum of 6 months [7] to more than a year [34]. As a result, our knowledge on the relationship between QoL and CD in long-COVID-19 is limited. For instance, the relationship between QoL and long-COVID-19 has so far been characterized from the perspective of patient characteristics, rather than the persistence of symptoms [35]. In this case, a meta-regression analysis of seven studies shows that poor QoL measured via self-reports was significantly higher among individuals post-COVID-19 who reported persistent fatigue, but not CD [35].

To fill this gap here we investigate the associations between physical- and mentalhealth-related QoL scores (obtained via the standardized measure SF-12 [36,37]) and the persistence of various symptoms at least 6 months after the diagnosis of SARS-CoV-2 infection. We hypothesize that individuals with persistent symptoms will report poorer physical and mental QoL at more than 6 months from COVID-19 diagnosis as compared to individuals who resolved all symptoms within that timeframe. We expect POD and PGD to have a similar adverse impact on mental health-related QoL, although not on physical health-related QoL. We expect such an impact on mental QoL to be significantly 
greater than in the general population. We anticipate respondents who endure persistent symptoms for longer to report worse mental QoL.

\section{Materials and Methods}

An online survey [38] in Italian was disseminated throughout Italy from May to August 2021 through social networks. Individuals who reported having had SARS-CoV-2 infection, confirmed by nasopharyngeal swab, at least 6 months prior were included in the study. Individuals with pre-existing history of $C D$ or other pathologies known to affect $C D$ or QoL (i.e., head trauma, surgery or radiotherapy of the craniofacial region, psychiatric or neurological disease) were excluded from the analysis.

In the first part of the survey, demographic information (only age and sex) and the inclusion criteria were assessed. On the basis of the COVID-19 symptom index [39], information was collected on which symptoms were present during the active COVID-19 infection and if any symptom was still present at the time of completion of the questionnaire, at least 6 months following initial COVID-19 diagnosis. All COVID-19 symptoms were assessed as binary responses (i.e., present or absent). Respondents were also asked to rate olfactory and gustatory function, both during COVID-19 and at the time of completion of the survey, with a visual analogue scale (VAS) ranging from 0 (perception completely absent) to 10 (typical perception). Finally, the Italian version of the SF-12 questionnaire [40] was administered to the respondents.

SF-12 [36,37] is a validated and widely used instrument that provides a self-reported outcome measure of individuals' QoL through eight domains: (i) limitations in physical activities due to health problems; (ii) limitations in social activities due to physical or emotional problems; (iii) limitations in usual role activities because of physical health problems; (iv) bodily pain; (v) general mental health; (vi) limitations in usual role activities due to emotional problems; (vii) vitality; and (viii) general health perceptions. The questionnaire allows to obtain two scores ranging from 0 to 100: the physical component summary (PCS) and the mental component summary (MCS), which represent an index of individual physical and mental QoL, respectively. The PCS and the MCS scores are transformed to have a mean of 50 and a standard deviation of 10 . Thanks to this standardization, scores greater than or equal to 50 are directly interpreted as QoL above that reported by the average of the general population and scores below 50 are directly interpreted as QoL below that reported by the average of the general population $[36,37,41]$.

The study was conducted in accordance with the Declaration of Helsinki and adhered to Good Clinical Practice guidelines. Approval for this exempt protocol for anonymized data collection was obtained from the University Hospital of Cagliari Ethics committee (approval no. 2021/7118-28 April 2021).

\section{Statistical Analysis}

Statistical analyses were performed using R 3.6.3 and RStudio 1.3.952 (Boston, MA, USA). Categorical variables are reported as frequencies and/or percentages. Descriptive statistics for quantitative variables are reported as the mean \pm standard deviation (SD) or median (interquartile range [IQR]). The Mann-Whitney $U$ test was performed to evaluate the statistical significance of differences in PCS and MCS between two groups of respondents: those whose symptoms persist more than 6 months after the initial COVID-19 diagnosis, and those whose symptoms have remitted within that timeframe. One sample $t$-tests with $\mathrm{mu}=50$ were run to determine whether PCS and MCS in respondents reporting POD or PGD were significantly different from the general population. To reduce the magnitude of type II statistical error, the analysis was conducted only for symptoms that persisted in at least 32 respondents. This sample size was identified by using $G^{*}$ power 3.1 (Heinrich Heine University Dusseldorf, Dusseldorf, Germany) and considering 0.5 Cohen's $\mathrm{D}, 80 \%$ power and $10 \%$ margin of error. We ran separate multiple regression models via the lme4 package to predict PCS and MCS based on olfactory and gustatory VAS ratings, age 
sex, and time from COVID-19 diagnosis. For all analyses, the level of statistical significance was set at $p<0.05$ with a $95 \%$ confidence interval.

\section{Results}

From 18 May to 18 August 2021, we collected 470 complete responses (63 incomplete responses were excluded) to the survey. Of these, 39 responses were not considered for analysis as they did not meet the inclusion criteria: absence of a confirmed diagnosis of infection $(n=23)$, less than 6 months follow-up $(n=10)$, previous CD or severe comorbidities $(n=6)$. The final analyses were run on 431 responses from unique individuals.

The sample included 329 females (76.3\%) and 102 males $(23.7 \%)$ with a mean age of $38.4 \pm 12.5$ years old (range 12-71 years). The mean distance from diagnosis of SARS-CoV-2 infection was $253.4 \pm 70.5$ days (range 181-486 days). At the time of completion of the survey (at least 6 months after infection), 73.3\% of respondents had at least one symptom persisting from the initial COVID-19 diagnosis (Table 1).

Table 1. Survey-based frequency of Coronavirus Disease 2019 (COVID-19) symptoms during acute infection and at $>6$ months post-acute COVID-19 infection.

$\left.\begin{array}{ccc}\hline \text { Symptom } & \begin{array}{c}\text { During Acute } \\ \text { COVID-19 Infection } \\ \boldsymbol{n ( \% )}\end{array} & \begin{array}{c}>\text { 6 Months Post-Acute } \\ \text { COVID-19 Infection }\end{array} \\ \boldsymbol{n} \mathbf{( \% )}\end{array}\right)$

The most frequent persistent symptoms were: fatigue (185 cases, $42.9 \%$ ), olfactory dysfunction (127 cases, 29.5\%), gustatory dysfunction (96 cases, 22.3\%) and muscle pain (83 cases, 19.3\%). Specifically, of the 306 patients who self-reported olfactory dysfunction during infection, $41.4 \%$ reported POD at the time of completing the questionnaire. The frequency of PGD among patients who self-reported olfactory dysfunction during infection was instead of $34.8 \%$. Table 2 details the frequency of chemosensory symptoms reported by respondents.

The POD reported were anosmia in 18 (4.2\%) and hyposmia in 109 cases (25.2\%). Among respondents with a persistent olfactory dysfunction, 87.4\% reported an associated qualitative dysfunction (e.g., parosmia or phantosmia). As for PGD, 12 respondents (2.8\%) reported ageusia, while hypogeusia was detected in 84 cases (19.5\%). Among respondents with PGD, 93.7\% reported dysgeusia in association with qualitative taste dysfunction.

The analysis of the effects of the persistence of one of the symptoms on QoL indices was carried out for all symptoms reported by at least 32 respondents as still present $>6$ months post-acute COVID-19 infection. A summary of the results of the analysis is shown in Table 3. Respondents reporting at least one persistent symptom had significantly worse PCS (symptomatic vs. asymptomatic: 59 (53.9-61.3) vs. $51.5(42.3-56.9), p<0.001$ ) and MCS (symptomatic vs. asymptomatic: 50.1 (45.8-54.9) vs. 45.9 (36.7-52.1), $p<0.001$ ) than respondents who resolved all symptoms at the time of completion of the survey. 
Table 2. Survey-based frequency of specific olfactory and gustatory dysfunctions during acute infection and at $>6$ months post-acute COVID-19 infection.

\begin{tabular}{ccc}
\hline & $\begin{array}{c}\text { During Acute } \\
\text { SARS-CoV-2 Infection } \\
\boldsymbol{n} \mathbf{( \% )}\end{array}$ & $\begin{array}{c}\text { >6 Months Post-Acute } \\
\text { SARS-CoV-2 Infection } \\
\boldsymbol{n} \mathbf{( \% )}\end{array}$ \\
\hline Olfactory dysfunction & & \\
Anosmia & $238(55.2 \%)$ & $18(4.2 \%)$ \\
Hyposmia & $68(15.8 \%)$ & $109(25.2 \%)$ \\
Normal & $125(29 \%)$ & $304(70.5 \%)$ \\
Parosmia & $41(9.5 \%)$ & $96(22.3 \%)$ \\
Phantosmia & $15(3.5 \%)$ & $28(6.5 \%)$ \\
VAS self-assessment & $3.6 \pm 4.2$ & $7.8 \pm 3$ \\
(0-10, mean \pm SD) & & \\
Gustatory dysfunction & $198(46 \%)$ & $12(2.8 \%)$ \\
Ageusia & $78(18.1 \%)$ & $84(19.5 \%)$ \\
Hypogeusia & $155(36 \%)$ & $335(77.7 \%)$ \\
Normal & $53(12.3 \%)$ & $90(20.9 \%)$ \\
Dysgeusia & $4.3 \pm 4.2$ & $8.3 \pm 2.8$ \\
VAS self-assessment & & \\
$(0-10$, mean \pm SD) & & \\
\hline
\end{tabular}

Table 3. Physical (PCS) and mental quality of life (QoL) (MCS) scores by presence of COVID-19 symptom persisting for $>6$ months post-acute COVID-19 diagnosis.

\begin{tabular}{|c|c|c|c|}
\hline $\begin{array}{l}\text { Symptom Persisting at }>6 \text { Months } \\
\text { Post-Acute COVID-19 Diagnosis }\end{array}$ & $\begin{array}{c}\text { Absent } \\
\text { (Median (IQR)) }\end{array}$ & $\begin{array}{c}\text { Present } \\
\text { (Median (IQR)) }\end{array}$ & $\begin{array}{c}\text { Mann-Whitney } \\
p \text {-Value }\end{array}$ \\
\hline \multicolumn{4}{|l|}{ Muscle pain } \\
\hline PCS & $55.1(49.7-60.3)$ & $37.8(25.2-48.5)$ & $<0.001$ \\
\hline MCS & $47.1(41.3-53.2)$ & $47.1(40.9-52.6)$ & 0.331 \\
\hline \multicolumn{4}{|l|}{ Joint pain } \\
\hline PCS & $55.3(49.6-60.4)$ & $37.6(25.2-47.4)$ & $<0.001$ \\
\hline MCS & $47.2(41.3-52.9)$ & $47.1(41-53.6)$ & 0.762 \\
\hline \multicolumn{4}{|l|}{ Fatigue } \\
\hline PCS & $57.1(52.5-61.1)$ & $46.3(34.9-53.2)$ & $<0.001$ \\
\hline MCS & $47.6(41.8-53.3)$ & $46.3(39.8-52.5)$ & 0.048 \\
\hline \multicolumn{4}{|l|}{ Headache } \\
\hline PCS & $54.6(47.6-60.1)$ & $46.1(34.7-52.6)$ & $<0.001$ \\
\hline MCS & $47.2(41.5-53)$ & $46(39.3-53.9)$ & 0.554 \\
\hline \multicolumn{4}{|l|}{ Gastrointestinal disorders } \\
\hline PCS & $53.7(46.5-59.8)$ & $46.5(28.2-53.2)$ & $<0.001$ \\
\hline MCS & $47.2(41.4-53.1)$ & $45.7(40.8-52.8)$ & 0.429 \\
\hline \multicolumn{4}{|l|}{ Olfactory dysfunction } \\
\hline PCS & $53.4(46.5-59.4)$ & $52.5(42.4-59.1)$ & 0.207 \\
\hline MCS & $49.6(44.2-54.2)$ & $41(33.9-46.3)$ & $<0.001$ \\
\hline \multicolumn{4}{|l|}{ Gustatory dysfunction } \\
\hline PCS & $53.4(46.4-59.6)$ & $52.9(42.5-58.5)$ & 0.282 \\
\hline MCS & $48.8(43.7-54.1)$ & $39.1(33-44.2)$ & $<0.001$ \\
\hline \multicolumn{4}{|l|}{ Dyspnea } \\
\hline PCS & $53.9(47.6-59.9)$ & $39.9(29.3-51.8)$ & $<0.001$ \\
\hline MCS & $47.8(42.1-53.4)$ & $38.2(33.6-44.6)$ & $<0.001$ \\
\hline
\end{tabular}

Specifically, respondents who reported persisting muscle pain, joint pain, fatigue, headache, gastrointestinal disturbances, and dyspnea had significantly worse PCS than respondents for whom these symptoms had completely regressed (Table 3). Those experiencing persistent fatigue and dyspnea also showed significantly lower MCS than respondents who reported to have completely healed (Table 3).

Respondents reporting CD for at least 6 months post-COVID-19 diagnosis showed significantly worse mental QoL (but not physical) than respondents who reported that $\mathrm{CD}$ 
had completely regressed (Table 3 and Figure 1). When comparing the PCS of respondents with POD and PGD with the general population (mean $=50$ and sd $=10$ ), respectively, no significant differences emerge (POD: $t=-0.78, \mathrm{df}=126, p=0.44 ; \mathrm{PGD}: t=-0.67, \mathrm{df}=95$, $p=0.51$ ) (Figure 1A,B). However, MCS in both respondents with POD and PGD is worse than in the general population (POD: $t=-12.2, \mathrm{df}=126, p<2.2 \times 10^{-16}$; PGD: $t=-12.6$, $\left.\mathrm{df}=95, p<2.2 \times 10^{-16}\right)($ Figure $1 \mathrm{C}, \mathrm{D})$.
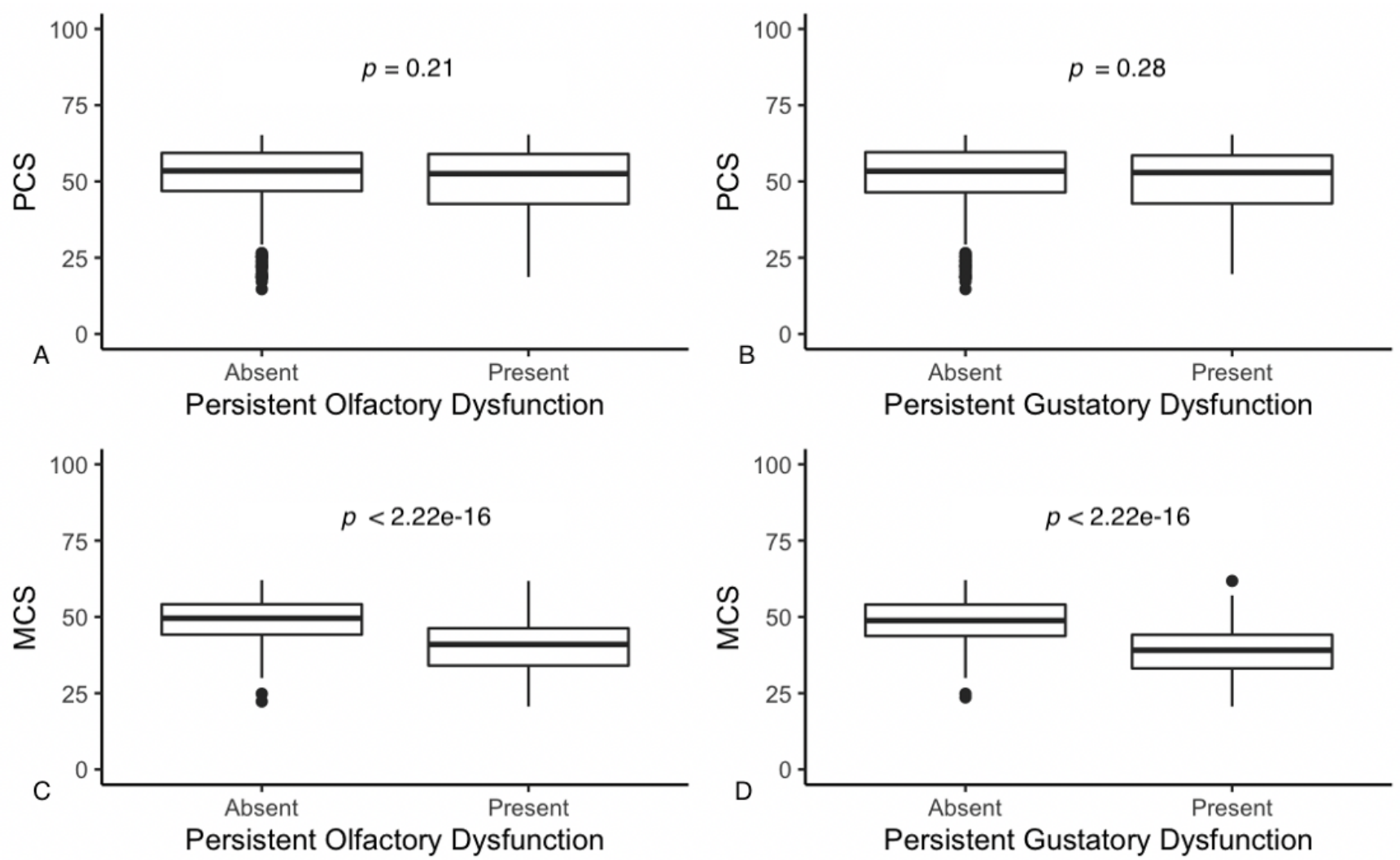

Figure 1. Results of the analysis of the effects of POD $(A, C)$ and PGD $(\mathbf{B}, \mathbf{D})$ on the QoL of respondents by mental and physical component scores. The shaded rectangle identifies the IQR around the median, which corresponds to the horizontal bold line within the rectangle. The error bars identify the maximum and minimum values. Respondents reporting CD for at least 6 months post-COVID-19 diagnosis showed significantly worse mental QoL than respondents who reported that CD had completely regressed.

Multiple regression analyses indicate that the olfactory VAS rating $(t=7.63, \mathrm{df}=425$, $\left.p=1.5 \times 10^{-13}\right)$ and nominally the gustatory VAS rating $(t=1.95, \mathrm{df}=425, p=0.05)$ predict the MCS score. Age, sex and temporal distance from the COVID-19 acute diagnosis were not significant factors in this prediction (Figure 2). Only age had a significant effect in the prediction of PCS $\left(t=-7.45, \mathrm{df}=425, p=5.32 \times 10^{-13}\right)$, in that younger participants report better PCS. 

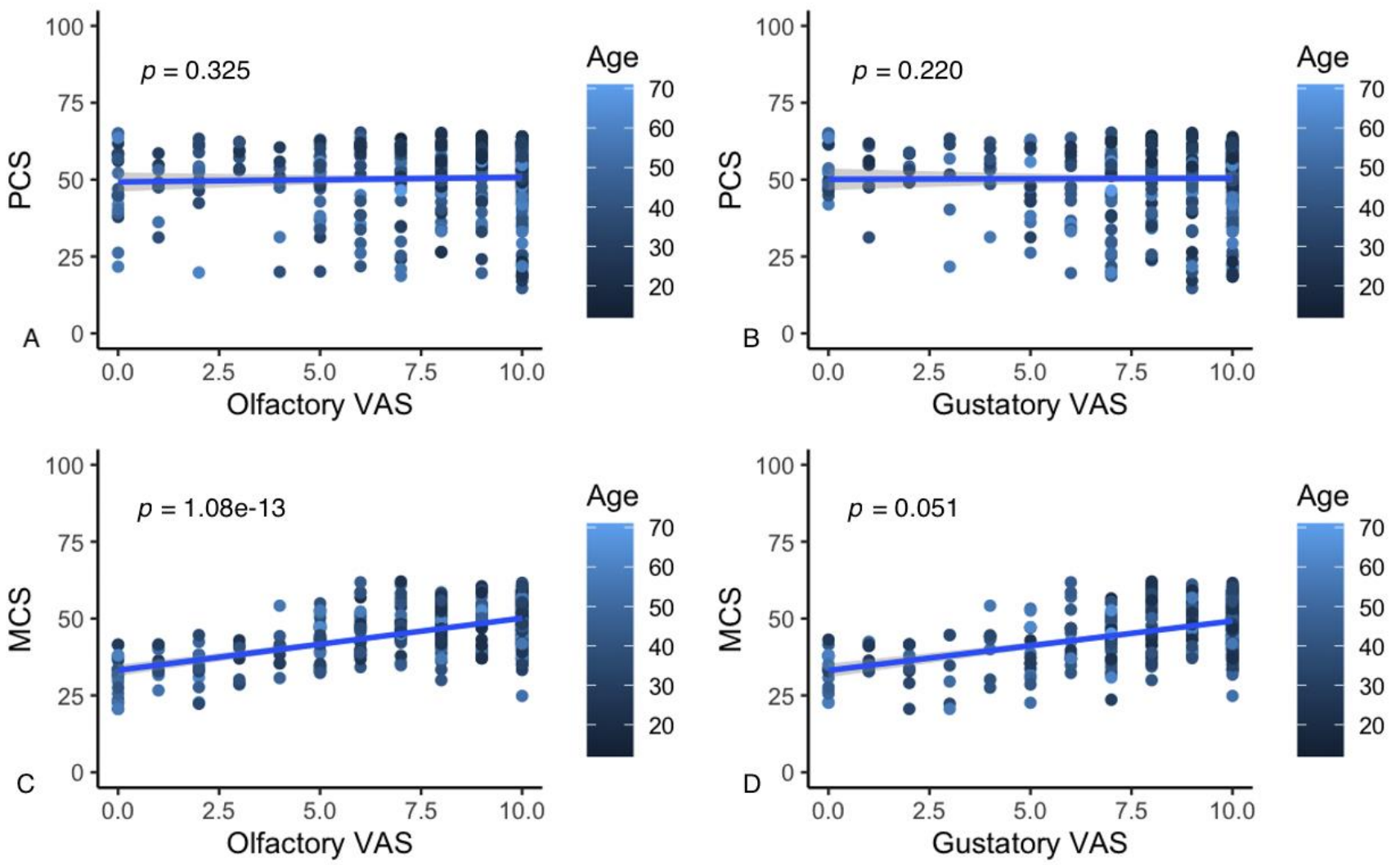

Figure 2. Results of the correlation analysis between olfactory and gustatory VAS scores and PCS $(\mathbf{A}, \mathbf{B})$ and MCS (C,D).

\section{Discussion}

The SARS-CoV-2 pandemic helped put taste and smell disorders in the headlines [42-46]. These pathologies were the prerogative of a narrow circle of specialists and mostly unknown to the lay public. Even before the pandemic, viral infections were the most frequent cause of persistent anosmia [47], yet the COVID-19 pandemic significantly increases the magnitude of this phenomenon. First, due to the very high number of patients with POD and PGD: up to $67 \%$ of all those who have had symptomatic COVID-19 [2-12,48-53]. Moreover, CD are also proving a frequent symptom in reinfections [13,14] and in COVID-19 in vaccinated individuals [15]. It has not yet been clarified what the frequency of persistent disturbances is in these groups of individuals, but if the prevalence recorded in cases of primary infection were confirmed, it would mean that this problem may not end with the immunization of the population. Second, the identification of the pathogenesis [54-61] and risk factors [2-12,62-68] for the development of persistent $C D$ are in its infancy. For this reason, no effective therapies have yet been found for the prevention and treatment of COVID-19 related POD and PGD [69-75].

In the present study, POD and PGD were confirmed as one of the most frequent symptoms of long-COVID-19 with a prevalence of $24.6 \%$ and $19.5 \%$, respectively, second only to fatigue $(42.5 \%)$, a much more aspecific symptom [76]. In almost all cases, quantitative $\mathrm{CD}$ (i.e., anosmia/hyposmia, and ageusia/hypogeusia) was associated with qualitative CD (i.e., parosmia or dysgeusia) $>6$ months after diagnosis. Qualitative olfactory dysfunctions generally arise 2-3 months after $C D$ onset [77] and are due to aberrant regeneration of the connections between olfactory neurons and higher brain areas [78]. Overall, qualitative disorders have been more associated with severe reduction in QoL than purely quantitative disorders [79].

The presence of at least one persistent symptom was shown to be related to significantly lower PCS and MCS values compared to respondents who resolved all symptoms 
$>6$ months after COVID-19 diagnosis. In particular, all symptoms that affect the respondent's ability to carry out physical activities normally (i.e., fatigue, dyspnea, muscle and joint pain) were associated with a significant reduction in PCS. POD and PGD were instead accompanied by a significant reduction in MCS alone. Such a reduction in the mental component of QoL is greater than that reported for pathologies, such as chronic renal failure requiring long-term dialysis [80], chronic ischemic heart disease [81] and oncological problems [82]. The strength of the relationship between POD or PGD and MCS is underlined by the strong and significant relationship detected between self-reported VAS assessment of smell and, marginally, of taste and MCS values, the net effects of age, sex and the duration of the disease (Figure 2).

Older respondents in our sample reported lower PCS. Interestingly, physically impacting symptoms, such as muscle and joint pain, were not accompanied by significant reductions in MCS. This could be linked to the fact that over time the symptoms that cause physical limitations tend to have a less marked impact on the psychological component of the individual who can, therefore, return to acceptable MCS values [83].

Such an adaptation effect is not true for persistent $C D$, which is associated with severe psychological consequences even long after disease onset. Indeed, 100 days postCOVID-19 self-identification, the risk for individuals with $C D$ to transition to depression or a suicidal ideation risk state is greater than for individuals without CD [22]. This finding underlines the importance of taste and smell as a determinant of the mental QoL of the individual as their integrity is crucial for the thriving of vital functions $[17,74,84]$. Importantly, the duration of the pandemic provides a natural constraint within which to assess the effects of CD on QoL. Nonetheless, adverse consequences on nutritional and mental health are expected to snowball over the years, and the healthcare system needs to build the infrastructure to address these issues, including support services as well as the development of therapies to cure $\mathrm{CD}$ for the millions of individuals battling long-COVID. The lack of monitoring on emerging $\mathrm{CD}$ at the beginning of the pandemic has already represented a lost opportunity to implement effective public health decisions [85].

This study has some limitations. First, it was not possible to perform a psychophysical evaluation of smell and taste; the self-reported evaluation of olfactory and gustatory loss and recovery alone can introduce bias both in terms of the underestimation of the loss and overestimation of recovery [86-88]. Second, respondents were asked to report symptoms that occurred during the infection that was active at least 6 months prior to engaging with the survey, and this may have introduced recall biases [89]. Third, in order to avoid an overestimation of persistent symptoms and to be able to count on reliable prevalence, the survey was not disseminated through direct channels with groups of individuals affected by long-COVID-19, but was addressed to anyone who had been infected with SARS-CoV-2 in the previous 6 months. However, it is possible that respondents with persistent symptoms were more motivated to respond to the survey. Additionally, given the overlap between respondents reporting simultaneously quantitative and qualitative POD and PGD, it was not possible to address the effect of these disorders separately on QoL. Finally, voluntary recruitment may have introduced selection biases [89].

\section{Conclusions}

POD and PGD are a frequent symptom of the long-COVID-19 syndrome and significantly reduce QoL, specifically in the mental health component. This evidence should stimulate the establishment of appropriate infrastructure to support individuals with persistent $C D$, while research on effective therapies scales up. In particular, these patients should be managed by multidisciplinary teams that include psychiatrists and nutritionists as well as specialists in the treatment of $\mathrm{CD}$. The results of this study help to underline the impact that POD and PGD are having on these individuals and should push us to focus research on the risk factors that identify COVID-19 patients at risk of developing a persistent disorder. The persistence of a long-term $\mathrm{CD}$ can in fact be a source of depression, eating disorders and social isolation $[17,21-25]$. Therefore, it is important to treat these patients early to 
avoid these important psychological morbidities and because the regression of the disorder is all the more difficult the longer the treatment is delayed $[71,73,74]$.

Author Contributions: Conceptualization, L.A.V., C.G. and G.D.R.; methodology, L.A.V., C.G., G.D., G.S., F.M. and G.D.R.; formal analysis, L.A.V. and V.P.; investigation, C.G. and A.B.; literature review, J.R.L., S.S., P.P. and P.B.-R.; original draft preparation, L.A.V., C.G., G.D., G.S., F.M. and A.B.; review and editing, J.R.L., S.S., P.P., F.B., C.H., P.B.-R., C.H. and V.P.; visualization, A.B., J.R.L., S.S. and P.P.; supervision, G.D.R., F.B. and P.P.; project administration, G.D.R. All authors have read and agreed to the published version of the manuscript.

Funding: This research received no external funding.

Institutional Review Board Statement: The study was conducted according to the guidelines of the Declaration of Helsinki, and approved by the Ethics Committee of the University Hospital of Cagliari (2021/7118-28 April 2021).

Informed Consent Statement: Survey data were used according to the aforementioned protocol, which was accorded exempt status, since the survey precluded the specific identification of respondents.

Data Availability Statement: L.A. Vaira and C. Gessa had full access to all data in the study and take responsibility for the integrity of the data and the accuracy of the data analysis.

Conflicts of Interest: The authors declare no conflict of interest.

\section{References}

1. Halpin, S.; O'Connor, R.; Sivan, M. Long COVID and chronic COVID syndromes. J. Med. Virol. 2021, 93, 1242-1243. [CrossRef]

2. Otte, M.S.; Bork, M.-L.; Zimmermann, P.H.; Klussmann, J.P.; Luers, J.C. Persisting olfactory dysfunction improves in patients 6 months after COVID-19 disease. Acta Oto-Laryngol. 2021, 141, 626-629. [CrossRef]

3. Lechien, J.R.; Chiesa-Estomba, C.M.; Beckers, E.; Mustin, V.; Ducarme, M.; Journe, F.; Marchant, A.; Jouffe, L.; Barillari, M.R.; Cammaroto, G.; et al. Prevalence and 6-month recovery of olfactory dysfunction: A multicentre study of 1363 COVID-19 patients. J. Intern. Med. 2021, 290, 451-461. [CrossRef]

4. Bussière, N.; Mei, J.; Lévesque-Boissonneault, C.; Blais, M.; Carazo, S.; Gros-Louis, F.; De Serres, G.; Dupré, N.; Frasnelli, J. Chemosensory dysfunctions induced by COVID-19 can persist up to 7 months: A study of over 700 healthcare workers. Chem. Senses 2021, 46, bjab038. [CrossRef]

5. Boscolo-Rizzo, P.; Menegaldo, A.; Fabbris, C.; Spinato, G.; Borsetto, D.; Vaira, L.A.; Calvanese, L.; Pettorelli, A.; Sonego, M.; Frezza, D.; et al. Six-Month Psychophysical Evaluation of Olfactory Dysfunction in Patients with COVID-19. Chem. Senses 2021, 46, bjab006. [CrossRef]

6. Riestra-Ayora, J.; Yanes-Diaz, J.; Esteban-Sanchez, J.; Vaduva, C.; Molina-Quiros, C.; Larran-Jimenez, A.; Martin-Sanz, E. Longterm follow-up of olfactory and gustatory dysfunction in COVID-19: 6 months case-control study of health workers. Eur. Arch. Oto-Rhino-Laryngol. 2021, 278, 4831-4837. [CrossRef] [PubMed]

7. Petrocelli, M.; Cutrupi, S.; Salzano, G.; Maglitto, F.; Salzano, A.F.; Lechien, J.R.; Saussez, S.; Boscolo-Rizzo, P.; De Riu, G.; Vaira, A.L. Six-month smell and taste recovery rates in coronavirus disease 2019 patients: A prospective psychophysical study. J. Laryngol. Otol. 2021, 135, 436-441. [CrossRef] [PubMed]

8. Hopkins, C.; Surda, P.; Vaira, L.; Lechien, J.; Safarian, M.; Saussez, S.; Kumar, N. Six month follow-up of self-reported loss of smell during the COVID-19 pandemic. Rhinol. J. 2021, 59, 26-31. [CrossRef]

9. Niklassen, A.S.; Draf, J.; Huart, C.; Hintschich, C.; Bocksberger, S.; Trecca, E.M.C.; Klimek, L.; Le Bon, S.D.; Altundag, A.; Hummel, T. COVID-19: Recovery from Chemosensory Dysfunction. A Multicentre study on Smell and Taste. Laryngoscope 2021, 131, 1095-1100. [CrossRef] [PubMed]

10. Vaira, L.A.; Salzano, G.; Le Bon, S.D.; Maglio, A.; Petrocelli, M.; Steffens, Y.; Ligas, E.; Maglitto, F.; Lechien, J.R.; Saussez, S.; et al. Prevalence of Persistent Olfactory Disorders in Patients with COVID-19: A Psychophysical Case-Control Study with 1-Year Follow-up. Otolaryngol. Neck Surg. 2021. [CrossRef]

11. Boscolo-Rizzo, P.; Guida, F.; Polesel, J.; Marcuzzo, A.V.; Antonucci, P.; Capriotti, V.; Sacchet, E.; Cragnolini, F.; D’Alessandro, A.; Zanelli, E.; et al. Self-reported smell and taste recovery in coronavirus disease 2019 patients: A one-year prospective study. Eur. Arch. Oto-Rhino-Laryngol. 2022, 297, 515-520. [CrossRef] [PubMed]

12. Boscolo-Rizzo, P.; Hummel, T.; Hopkins, C.; Dibattista, M.; Menini, A.; Spinato, G.; Fabbris, C.; Emanuelli, E.; D'Alessandro, A.; Marzolino, R.; et al. High prevalence of long-term olfactory, gustatory, and chemesthesis dysfunction in post-COVID-19 patients: A matched case-control study with one-year follow-up using a comprehensive psychophysical evaluation. Rhinol. J. 2021, 59, 517-527. [CrossRef] [PubMed]

13. Lechien, J.R.; Chiesa-Estomba, C.M.; Vaira, L.A.; Saussez, S.; Hans, S. COVID-19 Reinfection and Second Episodes of Olfactory and Gustatory Dysfunctions: Report of First Cases. Ear Nose Throat J. 2020. [CrossRef] [PubMed] 
14. Lechien, J.R.; Chiesa-Estomba, C.M.; Radulesco, T.; Michel, J.; Vaira, L.A.; Le Bon, S.D.; Horoi, M.; Falanga, C.; Barillari, M.R.; Hans, S.; et al. Clinical features of patients who had two COVID-19 episodes: A European multicentre case series. J. Intern. Med. 2021, 290, 421-429. [CrossRef]

15. Vaira, L.A.; De Vito, A.; Lechien, J.R.; Chiesa-Estomba, C.M.; Mayo-Yàñez, M.; Calvo-Henrìquez, C.; Saussez, S.; Madeddu, G.; Babudieri, S.; Boscolo-Rizzo, P.; et al. New Onset of Smell and Taste Loss Are Common Findings Also in Patients with Symptomatic COVID -19 After Complete Vaccination. Laryngoscope 2022, 132, 419-421. [CrossRef]

16. Philpott, C.; Boak, D. The Impact of Olfactory Disorders in the United Kingdom. Chem. Senses 2014, 39, 711-718. [CrossRef]

17. Boesveldt, S.; Parma, V. The importance of the olfactory system in human well-being, through nutrition and social behavior. Z. Zellforsch. Mikrosk. Anat. 2021, 383, 559-567. [CrossRef]

18. Yan, C.H.; Faraji, F.; Bs, D.P.P.; Ostrander, B.T.; DeConde, A.S. Self-reported olfactory loss associates with outpatient clinical course in COVID-19. Int. Forum Allergy Rhinol. 2020, 10, 821-831. [CrossRef]

19. Hopkins, C.; Vaira, L.A.; De Riu, G. Self-reported olfactory loss in COVID-19: Is it really a favorable prognostic factor? Int. Forum Allergy Rhinol. 2020, 10, 926. [CrossRef]

20. Vaira, L.A.; Hopkins, C.; Petrocelli, M.; Lechien, J.R.; Soma, D.; Giovanditto, F. Do olfactory and gustatory psycho-physiocal scores have prognostic value in COVID-19 patients? A prospective study of 106 patients. J. Otolaryngol. Head Neck Surg. 2020, 49, 56. [CrossRef]

21. Speth, M.M.; Singer-Cornelius, T.; Oberle, M.; Gengler, I.; Brockmeier, S.J.; Sedaghat, A.R. Mood, anxiety and olfactory dysfunction in COVID-19: Evidence of central nervous system involvement? Laryngoscope 2020, 130, 2520-2525. [CrossRef] [PubMed]

22. Yom-Tov, E.; Lekkas, D.; Jacobson, N.C. Association of COVID19-induced anosmia and ageusia with depression and suicidal ideation. J. Affect. Disord. Rep. 2021, 5, 100156. [CrossRef] [PubMed]

23. Croy, I.; Symmank, A.; Schellong, J.; Hummel, C.; Gerber, J.; Joraschky, P.; Hummel, T. Olfaction as a marker for depression in humans. J. Affect. Disord. 2014, 160, 80-86. [CrossRef] [PubMed]

24. Neuland, C.; Bitter, T.; Marschner, H.; Gudziol, H.; Guntinas-Lichius, O. Health-related and specific olfaction-related quality of life in patients with chronic functional anosmia or severe hyposmia. Laryngoscope 2011, 121, 867-872. [CrossRef]

25. Kamrava, S.K.; Tavakol, Z.; Talebi, A.; Farhadi, M.; Jalessi, M.; Hosseini, S.F.; Amini, E.; Chen, B.; Hummel, T.; Alizadeh, R. A study of depression, partnership and sexual satisfaction in patients with post-traumatic olfactory disorders. Sci. Rep. 2021, 11, 1-8. [CrossRef]

26. Watson, D.L.B.; Campbell, M.; Hopkins, C.; Smith, B.; Kelly, C.; Deary, V. Altered smell and taste: Anosmia, parosmia and the impact of long COVID-19. PLoS ONE 2021, 16, e0256998. [CrossRef]

27. Ohla, K.; Tomer Green, M.G.V.; Hannum, M.E.; Bakke, A.J.; Moein, S.T.; Tognetti, A. Increasing incidence of parosmia and phantosmia in patients recovering from COVID-19 smell loss. medRxiv 2021. [CrossRef]

28. Saniasiaya, J.; Prepageran, N. Impact of olfactory dysfunction on quality of life in coronavirus disease 2019 patients: A sys-tematic review. J. Laryngol. Otol. 2021, 135, 947-952. [CrossRef] [PubMed]

29. Alshakhs, A.; AlMomen, A.; Alyaeesh, I.; AlOmairin, A.; Almutairi, A.A.; Alammar, Z.; AlMomen, H.; AlMomen, Z. The association of smell and taste dysfunction with COVID19, and their functional impacts. Indian J. Otolaryngol. Head Neck Surg. 2021, 1-6. [CrossRef] [PubMed]

30. Coelho, D.H.; Reiter, E.R.; Budd, S.G.; Shin, Y.; Kons, Z.A.; Costanzo, R.M. Quality of life and safety impact of COVID-19 associated smell and taste disturbances. Am. J. Otolaryngol. 2021, 42, 103001. [CrossRef]

31. Elkholi, S.M.A.; Abdelwahab, M.K.; Abdelhafeez, M. Impact of the smell loss on the quality of life and adopted coping strategies in COVID-19 patients. Eur. Arch. Oto-Rhino-Laryngol. 2021, 278, 3307-3314. [CrossRef] [PubMed]

32. Rass, V.; Beer, R.; Schiefecker, A.J.; Kofler, M.; Lindner, A.; Mahlknecht, P.; Heim, B.; Limmert, V.; Sahanic, S.; Pizzini, A.; et al. Neurological outcome and quality of life 3 months after COVID-19: A prospective observational cohort study. Eur. J. Neurol. 2021, 28, 3348-3359. [CrossRef] [PubMed]

33. Coons, S.J.; Rao, S.; Keininger, D.L.; Hays, R.D. A Comparative Review of Generic Quality-of-Life Instruments. PharmacoEconomics 2000, 17, 13-35. [CrossRef] [PubMed]

34. Lee, D.Y.; Lee, W.H.; Wee, J.H.; Kim, J.-W. Prognosis of Postviral Olfactory Loss: Follow-up Study for Longer than One Year. Am. J. Rhinol. Allergy 2014, 28, 419-422. [CrossRef]

35. Malik, P.; Patel, K.; Pinto, C.; Jaiswal, R.; Tirupathi, R.; Pillai, S. Post-acute COVID-19 syndrome (PCS) and health-related quality of life (HRQoL) - A systematic review and meta-analysis. J. Med. Virol. 2022, 94, 253-262. [CrossRef] [PubMed]

36. Ware Jr, J.; Kosinski, M.; Keller, S.D. A 12-item short-form health survey: Construction of scales and preliminary tests of relia-bility and validity. Med. Care 1996, 34, 220-223. [CrossRef] [PubMed]

37. Gandek, B.; Ware, J.E.; Aaronson, N.K.; Apolone, G.; Bjorner, J.B.; Brazier, J.E.; Bullinger, M.; Kaasa, S.; Leplege, A.; Prieto, L.; et al. Cross-Validation of Item Selection and Scoring for the SF-12 Health Survey in Nine Countries: Results from the IQOLA Project. International Quality of Life Assessment. J. Clin. Epidemiol. 1998, 51, 1171-1178. [CrossRef]

38. COVID-19 e Qualità della Vita. Available online: https:/ /it.surveymonkey.com/r/WSZ7TVS (accessed on 8 December 2021).

39. Lechien, J.R.; Chiesa-Estomba, C.M.; Hans, S.; Calvo-Henriquez, C.; Mayo-Yáñez, M.; Tucciarone, M.; Vaira, L.A.; Saussez, S.; Saibene, A.M. Validity and reliability of the COVID-19 symptom index, an instrument evaluating severity of general and otolaryngological symptoms. Acta Oto-Laryngol. 2021, 131, 615-620. [CrossRef] 
40. Kodraliu, G.; Mosconi, P.; Groth, N.; Carmosino, G.; Perilli, A.; Gianicolo, E.A. Subjective health status assessment: Evaluation of the Italian version of the SF-12 health survey. Results from the MiOS project. J. Epidemiol. Biostat. 2001, 6, 305-316. [CrossRef]

41. Vilagut, G.; Forero, C.G.; Pinto-Meza, A.; Haro, J.M.; de Graaf, R.; Bruffaerts, R.; Kovess, V.; de Girolamo, G.; Matschinger, H.; Ferrer, M.; et al. The Mental Component of the Short-Form 12 Health Survey (SF-12) as a Measure of Depressive Disorders in the General Population: Results with Three Alternative Scoring Methods. Value Health 2013, 16, 564-573. [CrossRef]

42. Vaira, L.A.; Lechien, J.R.; Khalife, M.; Petrocelli, M.; Hans, S.; Distinguin, L.; Salzano, G.; Cucurullo, M.; Doneddu, P.; Salzano, F.A.; et al. Psychophysical Evaluation of the Olfactory Function: European Multicenter Study on 774 COVID-19 Patients. Pathogens 2021, 10, 62. [CrossRef] [PubMed]

43. Parma, V.; Ohla, K.; Veldhuizen, M.G.; Niv, M.Y.; Kelly, C.E.; Bakke, A.J.; Cooper, K.W.; Bouysset, C.; Pirastu, N.; Dibattista, M.; et al. More Than Smell-COVID-19 Is Associated with Severe Impairment of Smell, Taste, and Chemesthesis. Chem. Senses 2020, 45, 609-622. [CrossRef]

44. Vaira, L.A.; Hopkins, C.; Salzano, G.; Petrocelli, M.; Melis, A.; Cucurullo, M.; Ferrari, M.; Gagliardini, L.; Pipolo, C.; Deiana, G.; et al. Olfactory and gustatory function impairment in COVID -19 patients: Italian objective multicenter-study. Head Neck 2020, 42, 1560-1569. [CrossRef] [PubMed]

45. Saniasiaya, J.; Islam, M.A.; Abdullah, B. Prevalence of olfactory dysfunction in coronavirus disease 2019 (COVID-19): A meta-analysis of 27,492 patients. Laryngoscope 2021, 131, 865-878. [CrossRef]

46. Lechien, J.R.; Chiesa-Estomba, C.M.; Vaira, L.A.; De Riu, G.; Cammaroto, G.; Chekkoury-Idrissi, Y.; Circiu, M.; Distinguin, L.; Journe, F.; de Terwangne, C.; et al. Epidemiological, otolaryngological, olfactory and gustatory outcomes according to the severity of COVID-19: A study of 2579 patients. Eur. Arch. Oto-Rhino-Laryngol. 2021, 278, 2851-2859. [CrossRef] [PubMed]

47. Doty, R.L. Epidemiology of smell and taste dysfunction. Huntingt. Dis. 2019, 164, 3-13. [CrossRef]

48. Vaira, A.L.; Hopkins, C.; Petrocelli, M.; Lechien, J.R.; Chiesa-Estomba, C.M.; Salzano, G.; Cucurullo, M.; Salzano, A.F.; Saussez, S.; Boscolo-Rizzo, P.; et al. Smell and taste recovery in coronavirus disease 2019 patients: A 60-day objective and prospective study. J. Laryngol. Otol. 2020, 134, 703-709. [CrossRef]

49. Hannum, E.M.; Ramirez, A.V.; Lipson, S.J.; Herriman, R.D.; Toskala, A.K.; Lin, C.; Joseph, P.V.; Reed, D.R. Objective sensory testing methods reveal a higher prevalence of olfactory loss in COVID-19-positive patients compared to subjective methods: A systematic review and meta-analysis. Chem. Senses 2020, 45, 865-874. [CrossRef]

50. Lechien, J.R.; Journe, F.; Hans, S.; Chiesa-Estomba, C.M.; Mustin, V.; Beckers, E.; Vaira, L.A.; De Riu, G.; Hopkins, C.; Saussez, S. Severity of Anosmia as an Early Symptom of COVID-19 Infection May Predict Lasting Loss of Smell. Front. Med. 2020, 7, 582802. [CrossRef]

51. Petrocelli, M.; Ruggiero, F.; Baietti, A.M.; Pandolfi, P.; Salzano, G.; Salzano, A.F.; Lechien, J.R.; Saussez, S.; De Riu, G.; Vaira, A.L. Remote psychophysical evaluation of olfactory and gustatory functions in early-stage coronavirus disease 2019 patients: The Bologna experience of 300 cases. J. Laryngol. Otol. 2020, 134, 571-576. [CrossRef]

52. Vaira, L.A.; Salzano, G.; Petrocelli, M.; Deiana, G.; Salzano, F.A.; De Riu, G. Validation of a self-administered olfactory and gustatory test for the remotely evaluation of COVID -19 patients in home quarantine. Head Neck 2020, 42, 1570-1576. [CrossRef]

53. Vaira, L.A.; Lechien, J.R.; Salzano, G.; Salzano, F.A.; Maglitto, F.; Saussez, S.; De Riu, G. Gustatory Dysfunction: A Highly Specific and Smell-Independent Symptom of COVID-19. Indian J. Otolaryngol. Head Neck Surg. 2020, 1-3. [CrossRef] [PubMed]

54. Le Bon, S.D.; Horoi, M. Is anosmia the price to pay in an immune-induced schorched-earth policy against COVID-19? Med. Hypotheses 2020, 143, 109881. [CrossRef] [PubMed]

55. Vaira, L.A.; Salzano, G.; Fois, A.G.; Piombino, P.; De Riu, G. Potential pathogenesis of ageusia and anosmia in COVID-19 pa-tients. Int. Forum Allergy Rhinol. 2020, 10, 1103-1104. [CrossRef] [PubMed]

56. Liang, F.; Wang, D.Y. COVID-19 anosmia: High prevalence, plural neuropathogenic mechanisms, and scarce neurotropism of SARS-CoV-2? Viruses 2021, 13, 2225. [CrossRef] [PubMed]

57. Vaira, L.A.; Hopkins, C.; Sandison, A.; Manca, A.; Machouchas, N.; Turilli, D.; Lechien, J.R.; Barillari, M.R.; Salzano, G.; Cossu, A.; et al. Olfactory epithelium histopathological findings in long-term coronavirus disease 2019 related anosmia. J. Laryngol. Otol. 2020, 134, 1123-1127. [CrossRef]

58. De Melo, G.D.; Lazarini, F.; Levallois, S.; Hautefort, C.; Michel, V.; Larrous, F.; Verillaud, B.; Aparicio, C.; Wagner, S.; Gheusi, G.; et al. COVID-19-related anosmia is associated with viral persistence and inflammation in human olfactory epithelium and brain infection in hamsters. Sci. Transl. Med. 2021, 13, eabf8396. [CrossRef]

59. Lechien, J.R.; Michel, J.; Radulesco, T.; Chiesa-Estomba, C.M.; Vaira, L.A.; De Riu, G.; Sowerby, L.; Hopkins, C.; Saussez, S. Clinical and Radiological Evaluations of COVID -19 Patients with Anosmia: Preliminary Report. Laryngoscope 2020, 130, $2526-2531$. [CrossRef] [PubMed]

60. Vaira, L.A.; Lechien, J.R.; Salzano, G.; Maglitto, F.; Saussez, S.; De Riu, G. The role of nasal immunoglobulins in the recovery of olfactory function in COVID-19 patients. Am. J. Otolaryngol. 2021, 103301. [CrossRef]

61. Lechien, J.R.; Radulesco, T.; Calvo-Henriquez, C.; Chiesa-Estomba, C.M.; Hans, S.; Barillari, M.R. ACE2 \& TMPRSS2 expressions in head \& neck tissues: A systemic review. Head Neck Pathol. 2021, 15, $225-235$.

62. Le Bon, S.; Payen, L.; Prunier, L.; Steffens, Y.; Horoi, M.; Vaira, L.A.; Hopkins, C.; Lechien, J.R.; Saussez, S. Making scents of loss of taste in COVID-19: Is self-reported loss of taste due to olfactory dysfunction? A prospective study using psychophysical testing. Int. Forum Allergy Rhinol. 2021, 11, 1504-1507. [CrossRef] 
63. Vaira, L.A.; Deiana, G.; Lechien, J.R.; De Vito, A.; Cossu, A.; Dettori, M. Correlations between olfactory psychophysical scores and SARS-CoV-2 viral load in COVID-19 patients. Laryngoscope 2021, 131, 2312-2318. [CrossRef]

64. Vaira, L.A.; De Vito, A.; Deiana, G.; Pes, C.; Giovanditto, F.; Fiore, V. Systemic inflammatory markers and psychophysical olfacory scores in coronavirus disease 2019 patients: Is there any correlation? J. Laryngol. Otol. 2021, 135, 723-728. [CrossRef]

65. Vaira, L.A.; De Vito, A.; Deiana, G.; Pes, C.; Giovanditto, F.; Fiore, V.; Lechien, J.R.; Le Bon, S.-D.; Saussez, S.; Madeddu, G.; et al. Correlations between IL-6 serum level and olfactory dysfunction severity in COVID-19 patients: A preliminary study. Eur. Arch. Oto-Rhino-Laryngol. 2021, 1-6. [CrossRef]

66. Amadu, A.M.; Vaira, L.A.; Lechien, J.R.; Scaglione, M.; Saba, L.; Lampus, M.L.; Profili, S.G.; Le Bon, S.; Salzano, G.; Maglitto, F.; et al. Analysis of the correlations between the severity of lung involvement and olfactory psychophysical scores in coronavirus disease 2019 (COVID-19) patients. Int. Forum Allergy Rhinol. 2021, 1-6. [CrossRef]

67. Saussez, S.; Sharma, S.; Thiriard, A.; Olislagers, V.; Duc, I.V.; Le Bon, S.; Khalife, M.; Hans, S.; De Riu, G.; Hopkins, C.; et al Predictive factors of smell recovery in a clinical series of 288 coronavirus disease 2019 patients with olfactory dysfunction. Eur. J. Neurol. 2021, 28, 3702-3711. [CrossRef]

68. Vaira, L.A.; Lechien, J.R.; De Riu, G.; Saussez, S. Chemosensory dysfunction in COVID-19: Is there really a correlation with viral load? Am. J. Otolaryngol. 2021, 42, 103037. [CrossRef] [PubMed]

69. Huart, C.; Philpott, C.M.; Altundag, A.; Alexander, W.; Fjaeldstad, A.W.; Frasnelli, J. Systemic corticosteroids in coro-navirus disease 2019 (COVID-19)-related smell dysfunction: An international view. Int. Forum Allergy Rhinol. 2021, 11, 1041-1046. [CrossRef] [PubMed]

70. Hopkins, C.; Alanin, M.; Philpott, C.; Harries, P.; Whitcroft, K.; Qureishi, A.; Anari, S.; Ramakrishnan, Y.; Sama, A.; Davies, E.; et al. Management of new onset loss of sense of smell during the COVID-19 pandemic - BRS Consensus Guidelines. Clin. Otolaryngol. 2021, 46, 16-22. [CrossRef] [PubMed]

71. Vaira, L.; Hopkins, C.; Petrocelli, M.; Lechien, J.; Cutrupi, S.; Salzano, G.; Chiesa-Estomba, C.; Saussez, S.; De Riu, G. Efficacy of corticosteroid therapy in the treatment of long- lasting olfactory disorders in COVID-19 patients. Rhinol. J. 2021, 59, 21-25. [CrossRef]

72. Whitcroft, K.L.; Hummel, T. Olfactory dysfunction in COVID-19: Diagnosis and management. JAMA 2020, 323, $2512-2514$. [CrossRef] [PubMed]

73. Vaira, L.A.; Lechien, J.R.; Dore, S.; Boccaletti, R.; Saussez, S.; De Riu, G. Specific Therapy of Olfactory Disorders in COVID-19 Patients is Essential for the Prevention of Long-term Dysfunction. Indian J. Otolaryngol. Head Neck Surg. 2021, 1-2. [CrossRef] [PubMed]

74. Saussez, S.; Vaira, L.A.; Chiesa-Estomba, C.M.; Le Bon, S.D.; Horoi, M.; Deiana, G.; Petrocelli, M.; Boelpaep, P.; Salzano, G.; Khalife, M.; et al. Short-Term Efficacy and Safety of Oral and Nasal Corticosteroids in COVID-19 Patients with Olfactory Dysfunction: A European Multicenter Study. Pathogens 2021, 10, 698. [CrossRef]

75. Lechien, J.R.; Hoch, C.C.; Vaira, L.A.; Saussez, S. The interest of fluticasone nasal spray in COVID-19 related anosmia is still not demonstrated. Am. J. Otolaryngol. 2021, 42, 103008. [CrossRef]

76. Skapinakis, P.; Lewis, G.; Mavreas, V. Unexplained Fatigue Syndromes in a Multinational Primary Care Sample: Specificity of Definition and Prevalence and Distinctiveness from Depression and Generalized Anxiety. Am. J. Psychiatry 2003, 160, 785-787. [CrossRef] [PubMed]

77. Cook, E.; Kelly, C.; Watson, D.; Hopkins, C. Parosmia is prevalent and persistent amongst those with COVID-19 olfactory dysfunction. Rhinol. J. 2021, 59, 222-224. [CrossRef] [PubMed]

78. Parker, J.K.; Kelly, C.E.; Gane, S.B. Molecular mechanism of parosmia. medRxiv 2021. [CrossRef]

79. Croy, I.; Nordin, S.; Hummel, T. Olfactory Disorders and Quality of Life-An Updated Review. Chem. Senses 2014, 39, 185-194. [CrossRef]

80. Lacson, E., Jr.; Xu, J.; Lin, S.F.; Dean, S.G.; Lazarus, J.M.; Hakim, R.M. A comparison of SF-36 and SF-12 composite scores and subsequent hospitalization and mortality risks in long-term dialysis patients. Clin. J. Am. Soc. Nephrol. 2010, 5, $252-260$. [CrossRef]

81. De Smedt, D.; Clays, E.; Annemans, L.; De Bacquer, D. EQ-5D Versus SF-12 in Coronary Patients: Are They Interchangeable? Value Health 2014, 17, 84-89. [CrossRef]

82. Abdullah, N.N.; Idris, I.B.; Shamsuddin, K. Health-related quality of life in Malaysian gastrointestinal cancer patients and their family caregivers-a comparison study. Support. Care Cancer 2020, 28, 1891-1899. [CrossRef]

83. Liu, D.; Besser, G.; Prem, B.; Speth, M.; Sedaghat, A.; Mueller, C. Individual importance of olfaction decreases with duration of smell loss. Rhinol. J. 2021, 59, 32-39. [CrossRef]

84. Hoskison, E.E. Olfaction, pheromones and life. J. Laryngol. Otol. 2013, 127, 1156-1159. [CrossRef] [PubMed]

85. Pierron, D.; Pereda-Loth, V.; Mantel, M.; Moranges, M.; Bignon, E.; Alva, O.; Kabous, J.; Heiske, M.; Pacalon, J.; David, R.; et al. Smell and taste changes are early indicators of the COVID-19 pandemic and political decision effectiveness. Nat. Commun. 2020, 11, 5152. [CrossRef] [PubMed]

86. Mazzatenta, A.; Neri, G.; D’Ardes, D.; De Luca, C.; Marinari, S.; Porreca, E.; Cipollone, F.; Vecchiet, J.; Falcicchia, C.; Panichi, V.; et al. Smell and Taste in Severe COVID-19: Self-Reported vs. Testing. Front. Med. 2020, 7, 589409. [CrossRef] [PubMed]

87. Lechien, J.R.; Saussez, S.; Maniaci, A.; Vaira, L.A. The study of recovery rates of COVID-19 olfactory and gustatory dysfunc-tions requires psychophysical evaluations. Am. J. Otolaryngol. 2021, 42, 103168. [CrossRef] [PubMed] 
88. Vaira, L.A.; Deiana, G.; Fois, A.G.; Pirina, P.; Madeddu, G.; De Vito, A.; Babudieri, S.; Petrocelli, M.; Serra, A.; Bussu, F.; et al. Objective evaluation of anosmia and ageusia in COVID-19 patients: Single-center experience on 72 cases. Head Neck 2020, 42 , 1252-1258. [CrossRef]

89. Coughlin, S.S. Recall bias in epidemiologic studies. J. Clin. Epidemiol. 1990, 43, 87-91. [CrossRef] 